\title{
"STRATEGI MARKETING PRODI FISIOTERAPI POLTEKKES JAKARTA III KEMENTERIAN KESEHATAN MENGHADAPI PERSAINGAN PASAR"
}

\author{
Toto Aminoto \\ Politeknik Kesehatan Jakarta III Kementerian Kesehatan \\ aminoto95@yahoo.com
}

\begin{abstract}
Abstrak
Latar belakang dari penelitian ini bertujuan untuk dapat mengetahui strategi pemasaran Prodi Fisioterapi Poltekkes Kemenkes Jakarta III. Dengan menggunakan analisa Five Forces Porter dihasilkan ancaman terhadap masuknya pesaing baru tergolong tinggi (skor 7,54); ancaman terhadap produk baru juga tergolong Rendah $(2,8)$; ancaman terhadap kekuatan tawar menawar pembeli tergolong rendah (skor 1,8); ancaman terhadap kekuatan tawar menawar pemasok tergolong rendah (skor 2,43); ancaman terhadap persaingan antar pesaing dalam industri sejenis tergolong tinggi (skor 7,67). Dengan matriks SWOT dihasilkan perhitungan posisi perusahaan pada kuadran satu yaitu kuadran yang mendukung kebijakan pertumbuhan yang agresif, maksudnya perusahaan harus lebih giat dalam mengatasi perkembangan pasar yang kompetetif dalam rangka memperluas pangsa pasar.
\end{abstract}

Kata Kunci: Five Forces Porter, SWOT, 4P

\section{LATAR BELAKANG}

Salah satu cara penentuan alternatif strategi yang sesuai dengan dasar kondisi internal serta pengaruh lingkungan eksternal Prodi fisioterapi poltekkes Jakarta III Kementerian Kesehatan adalah menggunakan analisa Five Forces Porter, analisa SWOT/TOWS. Dengan analisa ini diharapkan prodi fisioterapi poltekkes Jakarta III Kementerian Kesehatan dapat menentukan tujuan usaha yang 
realistis, sesuai dengan kondisi perusahaan (Sutojo dan Kleisteuber, 2008). Analisa ini diaplikasikan pula untuk mengetahui strategi yang tepat bagi Prodi fisioterapi poltekkes Jakarta III Kementerian Kesehatan dengan mengacu pada kondisi internal dan eksternalnya. Dimana Prodi fisioterapi adalah Prodi yang paling baru berdiri beberapa tahun belakangan ini.

Menurut Timothy Bard (2008) lima Kekuatan Persaingan adalah sebagai berikut :

1. Ancaman Pendatang Baru (The Threat Of New Entrants)

2. Daya Tawar Pe1 anggan (The Bargaining Power Of Costumers)

3. Daya Tawar Pemasok (The Bargaining Power Of Suppliers)

4. Ancaman Produk atau Jasa Substitusi (The Threat Of Substitutes Products Or Services)

5. Persaingan Diantara Kontestan Yang Ada (The Jockeying Among Current Contestants or Rivahy Among Existing Firms)

\section{ANALISA SWOT}

Analisis SWOT adalah identifikasi berbagai faktor secara sistematis untuk merumuskan strategi pemasaran. Strategi ini dengan memaksimalkan kekuatan dan peluang, namun secara simultan dapat meminimalkan kelemahan dan ancaman (Rangkuti, 2006).

Menurut Anne Gregory (2004) elemen-elemen analisis SWOT terdiri dari:

a. Strenghts (S), yaitu kekuatan/keunggulan yang dimiliki oleh perusahaanuntuk memenangkan persaingan.

b. Weakness (W), yaitu kelemahan yang dimiliki oleh perusahaan yang dapat menghambat perusahaan dalam persaingan.

c. Opportunities (O), yaitu kesempatan/peluang yang harus dimanfaatkanoleh perusahaan untuk memenangkan persaingan.

d. Threats $(\mathrm{T})$, yaitu ancaman yang menghambat perusahaan untukmemenangkan persaingan. 


\section{DIAGRAM SWOT}

Diagram SWOT digunakan untuk memperoleh alternatif strategi yang tepat untuk mendukung perencanaan strategi bisnis serta sebagai perbandingan alternatif strategi lainnya. Diagram SWOT sendiri terbagi atas empat kuadran dimana hasil kuadran tersebut diperoleh dari hasil kalkulasi matriks IFAS dan matriks EFAS.:

\section{BERBAGAI PELUANG}

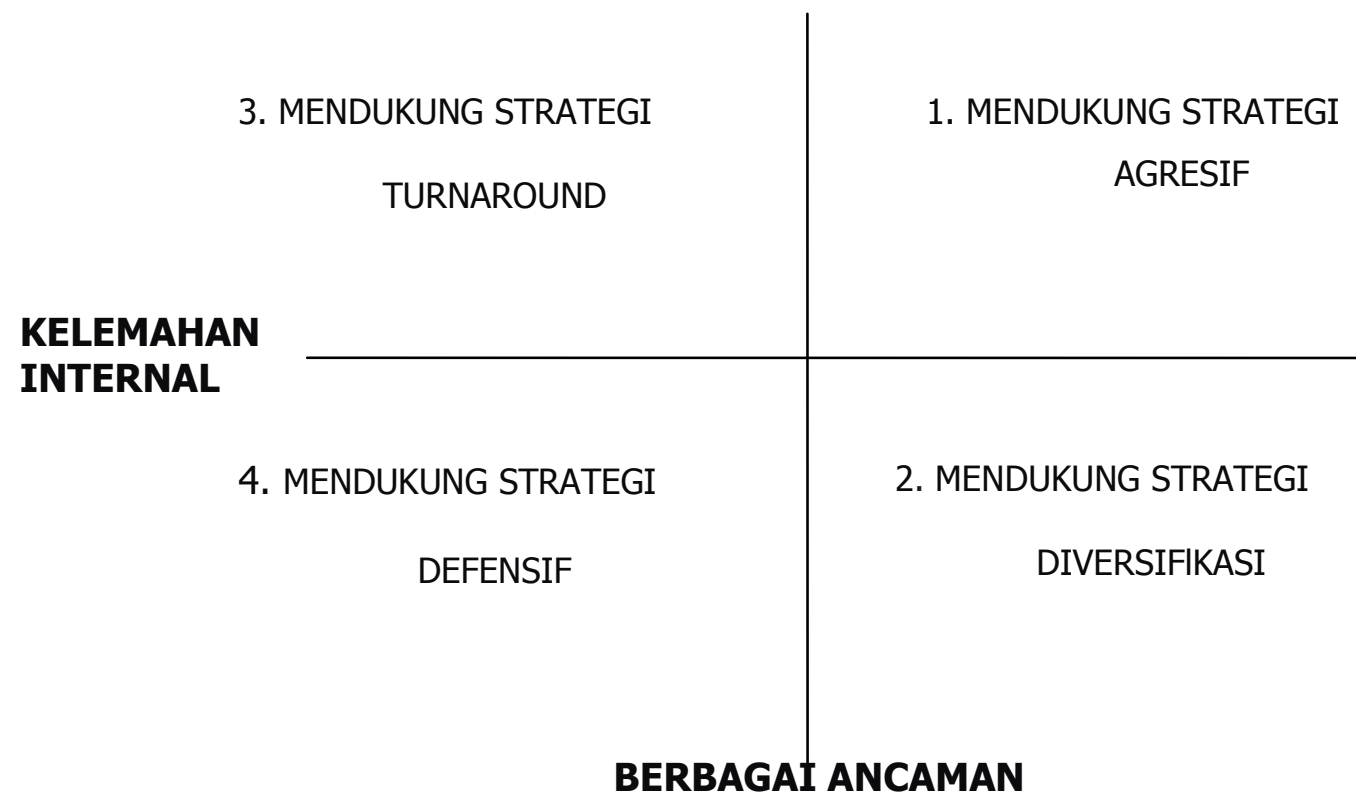

Gambar 1 Diagram Analisa SWOT

Sumber : Rangkuti (2006)

Tabel 1 Perhitungan

\begin{tabular}{|c|l|l|l|l|}
\hline \multicolumn{5}{|c|}{ 1.Masuknya Persaing Baru } \\
$\begin{array}{c}\text { No } \\
\text { yertan }\end{array}$ & Variabel & Indikator & Ranking & Bobot \\
\hline 1 & $\begin{array}{l}\text { Kebutuhan } \\
\text { modal }\end{array}$ & $\begin{array}{l}\text { Membuat prodi baru fisioterai } \\
\text { membutuhkan investasi yang }\end{array}$ & 7 & 0,23 \\
\hline
\end{tabular}




\begin{tabular}{|c|c|c|c|c|}
\hline & & tidak sedikit & & \\
\hline 2 & Perizinan & $\begin{array}{l}\text { Mendapatkan izin dari DIKTI } \\
\text { mudah }\end{array}$ & 8 & 0,27 \\
\hline 3 & $\begin{array}{l}\text { Kebijakan } \\
\text { pemerintah }\end{array}$ & $\begin{array}{l}\text { Kebijakan pemerintah dibidang } \\
\text { kefisioterapian sangat } \\
\text { mendukung }\end{array}$ & 8 & 0,27 \\
\hline 4 & $\begin{array}{l}\text { Loyalitas } \\
\text { pelanggan }\end{array}$ & $\begin{array}{l}\text { Pelanggan pengguna jasa lulusan } \\
\text { fisioterapi sangat loyal }\end{array}$ & 7 & 0,23 \\
\hline & Total & & 30 & 1 \\
\hline \multicolumn{5}{|c|}{ 2.Ancaman Produk Pengganti } \\
\hline 5 & $\begin{array}{l}\text { Produk } \\
\text { pengganti }\end{array}$ & $\begin{array}{l}\text { Terdapat keterbatasan perguruan } \\
\text { tinggi yang membuka prodi } \\
\text { Fisioterapi (account officer) }\end{array}$ & 2 & 0,4 \\
\hline 6 & $\begin{array}{l}\text { Tarif produk } \\
\text { pengganti }\end{array}$ & $\begin{array}{l}\text { Tarif perguruan tinggi yang } \\
\text { membuka prodi Fisioterapi } \\
\text { lebih mahal }\end{array}$ & 2 & 0,4 \\
\hline 7 & $\begin{array}{l}\text { Pangsa pasar } \\
\text { produk } \\
\text { pengganti }\end{array}$ & $\begin{array}{l}\text { Pangsa pasar pengganti jasa } \\
\text { fisioterapi lebih besar namun } \\
\text { trennnya cenderung menurun }\end{array}$ & 1 & 0,2 \\
\hline & Total & & 5 & 1 \\
\hline \multicolumn{5}{|c|}{ 3.Kekuatan Tawar Menawar Pelanggan } \\
\hline 8 & $\begin{array}{l}\text { Pangsa pasar } \\
\text { investor }\end{array}$ & $\begin{array}{l}\text { Jumlah perguruan tinggi yang } \\
\text { ada Prodi fisioterapi hanya } \\
\text { terpusat pada beberapa kota saja }\end{array}$ & 2 & 0,4 \\
\hline 9 & $\begin{array}{l}\text { Informasi } \\
\text { produk }\end{array}$ & $\begin{array}{l}\text { Masyarakat memiliki informasi } \\
\text { lengkap mengenai biaya } \\
\text { perkuliahan di fisioterapi }\end{array}$ & 1 & 0,2 \\
\hline 10 & $\begin{array}{l}\text { Biaya beralih } \\
\text { ke kompetitor }\end{array}$ & $\begin{array}{l}\text { Beralih ke kampus fisioterapi } \\
\text { lain mudah }\end{array}$ & 2 & 0,4 \\
\hline & Total & & 5 & 1 \\
\hline \multicolumn{5}{|c|}{ 4.Kekuatan Tawar Menawar Pemasok } \\
\hline 11 & Dominasi & Pemasok perangkat alat & 2 & 0,286 \\
\hline
\end{tabular}




\begin{tabular}{|c|c|c|c|c|}
\hline & pemasok. & $\begin{array}{l}\text { fisioterapi didominasi oleh } \\
\text { sedikit pemain. }\end{array}$ & & \\
\hline 12 & $\begin{array}{l}\text { Produk } \\
\text { pemasok }\end{array}$ & $\begin{array}{l}\text { Teknologi alat fisioterapi } \\
\text { sangat penting dalam } \\
\text { keberhasilan pendidikan } \\
\text { Fisioterapi }\end{array}$ & 3 & 0,429 \\
\hline 13 & $\begin{array}{l}\text { Pasar } \\
\text { pemasok }\end{array}$ & $\begin{array}{l}\text { Poltekkes Jakarta III merupakan } \\
\text { pelanggan yang penting bagi } \\
\text { pemasok }\end{array}$ & 2 & 0,286 \\
\hline & Total & & 7 & 1 \\
\hline \multicolumn{5}{|c|}{ 5. Persaingan antar pesaing dalam industri jasa sejenis } \\
\hline 14 & $\begin{array}{l}\text { Jumlah } \\
\text { pesaing }\end{array}$ & $\begin{array}{l}\text { Jumlah perguruan tinggi yang } \\
\text { membuka Prodi Fisioterapi } \\
\text { mulai banyak dengan kekuatan } \\
\text { yang beragam }\end{array}$ & 9 & 0,30 \\
\hline 15 & $\begin{array}{l}\text { Diferensiasi } \\
\text { produk/jasa }\end{array}$ & $\begin{array}{l}\text { Hanya sedikit perbedaan service } \\
\text { dengan pesaing }\end{array}$ & 8 & 0,27 \\
\hline 16 & Pertumbuhan & $\begin{array}{l}\text { Potensi pertumbuhan perguruan } \\
\text { tinggi membuka Prodi } \\
\text { fisioterapi cukup tinggi }\end{array}$ & 7 & 0,23 \\
\hline \multirow[t]{2}{*}{17} & Biaya tetap & Biaya tetap tinggi & 6 & 0,20 \\
\hline & Total & & 30 & 1 \\
\hline
\end{tabular}

Sumber : Lampiran 1, Data diolah

Setelah didapatkan pembobotan selanjutnya perhitungan penilain dari pembobotan tersebut.

Tabel 2 
Perhitungan Bobot

\begin{tabular}{|c|c|c|c|c|}
\hline \multicolumn{5}{|c|}{ 1. Masuknya Pesaing Baru } \\
\hline $\begin{array}{c}\text { No } \\
\text { Pertanyaan }\end{array}$ & Indikator & Penilaian & Bobot & $\begin{array}{l}\text { Penilaian } \\
\text { x Bobot }\end{array}$ \\
\hline 1 & $\begin{array}{l}\text { Mem buat prodi baru } \\
\text { fisioterai membutuhkan } \\
\text { investasi yang tidak sedikit }\end{array}$ & 7 & 0,23 & 1,61 \\
\hline 2 & $\begin{array}{l}\text { Mendapatkan izin dari } \\
\text { DIKTI mudah }\end{array}$ & 8 & 0,27 & 2,16 \\
\hline 3 & $\begin{array}{l}\text { Kebijakan pemerintah } \\
\text { dibidang kefisioterapian } \\
\text { sangat mendukung }\end{array}$ & 8 & 0,27 & 2,16 \\
\hline 4 & $\begin{array}{l}\text { Pelanggan pengguna jasa } \\
\text { lulusan fisioterapi sangat } \\
\text { loyal }\end{array}$ & 7 & 0,23 & 1,61 \\
\hline & & 30 & 1 & 7,54 \\
\hline \multicolumn{5}{|c|}{ 2. Ancaman Produk Pengganti } \\
\hline 5 & $\begin{array}{l}\text { Terdapat keterbatasan } \\
\text { perguruan tinggi yang } \\
\text { membuka prodi Fisioterapi } \\
\text { (account officer) }\end{array}$ & 2 & 0,4 & 0,8 \\
\hline 6 & $\begin{array}{l}\text { Tarif perguruan tinggi yang } \\
\text { membuka prodi Fisioterapi } \\
\text { lebih mahal }\end{array}$ & 2 & 0,4 & 0,8 \\
\hline 7 & $\begin{array}{l}\text { Pangsa pasar pengganti } \\
\text { jasa fisioterapi lebih besar } \\
\text { namun trennnya cenderung } \\
\text { menurun }\end{array}$ & 1 & 0,2 & 1,2 \\
\hline & & 5 & 1 & 2,8 \\
\hline \multicolumn{5}{|c|}{ 3.Kekuatan Tawar Menawar Pembeli } \\
\hline 8 & $\begin{array}{l}\text { Jumlah perguruan tinggi } \\
\text { yang ada Prodi fisioterapi }\end{array}$ & 2 & 0,4 & 0,8 \\
\hline
\end{tabular}




\begin{tabular}{|c|c|c|c|c|}
\hline & $\begin{array}{l}\text { hanya terpusat pada } \\
\text { beberapa kota saja }\end{array}$ & & & \\
\hline 9 & $\begin{array}{l}\text { Masyarakat memiliki } \\
\text { informasi lengkap } \\
\text { mengenai biaya } \\
\text { perkuliahan di fisioterapi }\end{array}$ & 1 & 0,2 & 0,2 \\
\hline 10 & $\begin{array}{l}\text { Beralih ke kampus } \\
\text { fisioterapi lain mudah }\end{array}$ & 2 & 0,4 & 0,8 \\
\hline & & 5 & 1 & 1,8 \\
\hline \multicolumn{5}{|c|}{ 4.Kekuatan Tawar Menawar Pemasok } \\
\hline 11 & $\begin{array}{l}\text { Pemasok perangkat alat } \\
\text { fisioterapi didominasi oleh } \\
\text { sedikit pemain. }\end{array}$ & 2 & 0,286 & 0,57 \\
\hline 12 & $\begin{array}{l}\text { Teknologi alat fisioterapi } \\
\text { sangat penting dalam } \\
\text { keberhasilan pendidikan } \\
\text { Fisioterapi }\end{array}$ & 3 & 0,429 & 1,29 \\
\hline 13 & $\begin{array}{l}\text { Poltekkes Jakarta III } \\
\text { merupakan pelanggan yang } \\
\text { penting bagi pemasok }\end{array}$ & 2 & 0,286 & 0,57 \\
\hline & & 7 & 1 & 2,43 \\
\hline \multicolumn{5}{|c|}{ 5. Persaingan antar pesaing dalam industri sejenis } \\
\hline 14 & $\begin{array}{l}\text { Jumlah perguruan tinggi } \\
\text { yang membuka Prodi } \\
\text { Fisioterapi mulai banyak } \\
\text { dengan kekuatan yang } \\
\text { beragam }\end{array}$ & 9 & 0,30 & 2,7 \\
\hline 15 & $\begin{array}{l}\text { Hanya sedikit perbedaan } \\
\text { service dengan pesaing }\end{array}$ & 8 & 0,27 & 2,16 \\
\hline 16 & $\begin{array}{l}\text { Potensi pertumbuhan } \\
\text { perguruan tinggi membuka } \\
\text { Prodi fisioterapi cukup }\end{array}$ & 7 & 0,23 & 1,61 \\
\hline
\end{tabular}




\begin{tabular}{|l|l|c|l|l|}
\hline & tinggi & & & \\
\hline 17 & Biaya tetap tinggi & 6 & 0,20 & 1,20 \\
\hline & & $\mathbf{3 0}$ & $\mathbf{1}$ & $\mathbf{7 , 6 7}$ \\
\hline
\end{tabular}

Sumber : Lampiran 1, Data diolah

\section{HASIL ANALISIS FIVE FORCES PORTER}

Dari hasil perhitungan bobot didapatkan hasil bahwa :

1. Untuk ancaman terhadap masuknya pesaing baru tergolong TINGGI (skor 7,54).

2. Ancaman terhadap produk baru tergolong RENDAH (skor 2,8). .

3. Kekuatan Tawar Menawar Pembeli tergolong RENDAH (skor 1,8).

4. Kekuatan Tawar Menawar Pembeli tergolong RENDAH (skor 2,43).

5. Ancaman Terhadap Persaingan Antar Pesaing Dalam Industri Sejenis tergolong TINGGI (skor 7,67). karena bisa memberikan kemampuan fisioterpis yang lebih baik.

\subsection{MENENTUKAN MATRIK IFAS DAN EFAS}

Faktor-faktor strategis Prodi Fisioterapi poltekkes Jakarta III Kemenkes yang di dapat kemudian dimasukkan dalam bentuk Tabel IFAS dan EFAS sebelumnya dilakukan pembobotan terhadap masing-masing faktor strategi. Pemberian bobot internal dan eksternal di dasarkan pada perhitungan kategori nilai penilaian terhadap setiap faktor strategis, dari sini dilihat mana yang mempunyai pengaruh paling besar dan pengaruh terkecil untuk memberikan penilaian.Fungsi dari pembobotan dan rating adalah untuk mengetahui faktor strategis Prodi Fisioterapi Poltekkes Jakarta III Kemenkes dan dapat memberikan dampak positif dan negatif. Dampak positif dapat menjadi faktor kekuatan dan peluang, sedang dampak negatif menjadi kelemahan dan ancaman.

Berikut ini Tabel pemberian nilai dan bobot serta pemberian bobot dan rating:

Tabel 3 : Penentuan Nilai Bobot IFAS

\begin{tabular}{|l|l|l|l|l|l|l|}
\hline Variabel & $(1)$ & $(2)$ & $(3)$ & $(4)$ & Penilaian & Bobot \\
\hline
\end{tabular}




\begin{tabular}{|c|c|c|c|c|c|}
\hline \multicolumn{6}{|c|}{ Kekuatan (STRENGTHS) } \\
\hline 1 & $\begin{array}{l}\text { Perguruan Tinggi } \\
\text { Negeri yang } \\
\text { memberikan rasa aman }\end{array}$ & & $\mathrm{x}$ & 4 & 0,12 \\
\hline 2 & $\begin{array}{l}\text { Prodi Fisioterapi } \\
\text { masih jarang } \\
\text { diselenggarakan oleh } \\
\text { perguruan tinggi lain }\end{array}$ & & $\mathrm{x}$ & 4 & 0,12 \\
\hline 3 & $\begin{array}{l}\text { Berada dalam posisi } 5 \\
\text { Prodi fisioterapi } \\
\text { terbaik di Indonesia }\end{array}$ & & $\mathrm{x}$ & 4 & 0,12 \\
\hline 4 & $\begin{array}{l}\text { Memiliki tim Dosen } \\
\text { yang bereputasi } \\
\text { nasional dan } \\
\text { internasional }\end{array}$ & $\mathrm{x}$ & & 3 & 0,09 \\
\hline 5 & 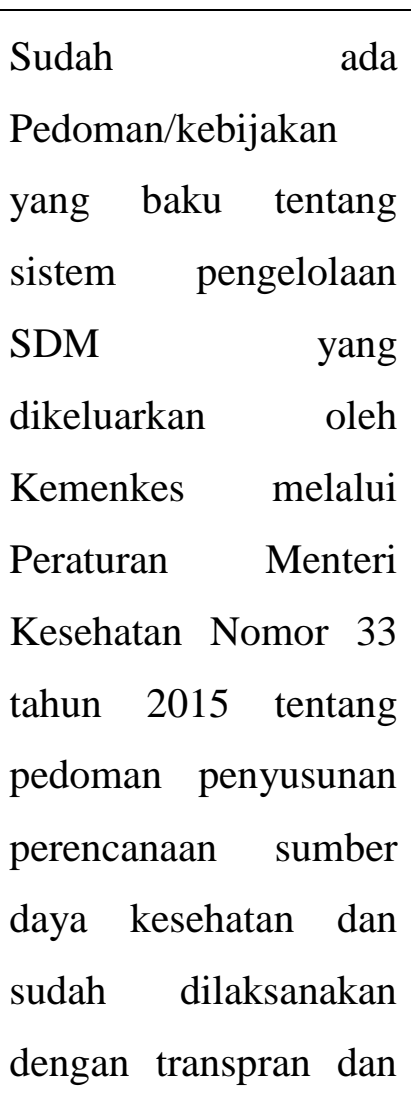 & & $\mathrm{x}$ & 4 & 0,12 \\
\hline
\end{tabular}




\begin{tabular}{|c|c|c|c|c|}
\hline & akuntabel & & & \\
\hline \multicolumn{5}{|c|}{ Kelemahan (WEAKNESS) } \\
\hline 1 & $\begin{array}{l}\text { Guru Besar belum } \\
\text { ada }\end{array}$ & $\mathrm{x}$ & 3 & 0,09 \\
\hline 2 & $\begin{array}{l}\text { Jabatan fungsional } \\
\text { dosen masih sedikit } \\
\text { dan sebagian besar } \\
\text { masih Asisten Ahli }\end{array}$ & $\mathrm{x}$ & 3 & 0,09 \\
\hline 3 & $\begin{array}{lr}\text { Jumlah penelitan dan } \\
\text { publikasi } & \text { ilmiah } \\
\text { secara } & \text { kuantitas } \\
\text { maupun } & \text { kualitas } \\
\text { masih kecil } & \end{array}$ & $\mathrm{x}$ & 2 & 0,06 \\
\hline 4 & $\begin{array}{l}\text { Jumlah dosen } \\
\text { sesuai prodi masih } \\
\text { kurang }\end{array}$ & $\mathrm{x}$ & 3 & 0,09 \\
\hline 5 & $\begin{array}{lr}\text { Dosen yang } \\
\text { pendidikan S2 } \\
\text { kefisioterapian } \\
\text { masih kurang }\end{array}$ & & 4 & 0,12 \\
\hline & Total & & 33 & \\
\hline
\end{tabular}

Sumber : Lampiran 2, Data diolah

Tabel 4. Penentuan Nilai Bobot EFAS

\begin{tabular}{|l|l|l|l|l|l|l|}
\hline Variabel & $(1)$ & $(2)$ & $(3)$ & $(4)$ & Penilaian & Bobot \\
\hline Peluang (Oportunity)
\end{tabular}




\begin{tabular}{|c|c|c|c|c|c|}
\hline 1 & $\begin{array}{l}\text { Adanya kesempatan } \\
\text { memperoleh } \\
\text { beasiswa untuk } \\
\text { pelatihan dan studi } \\
\text { lanjut baik dalam } \\
\text { negeri maupun luar } \\
\text { negeri } \\
\text { diberikan yang } \\
\text { pemerintah }\end{array}$ & & $\mathrm{x}$ & 4 & 0,17 \\
\hline 2 & $\begin{array}{l}\text { Terbukanya } \\
\text { kesempatan dosen } \\
\text { vokasi untuk } \\
\text { mendapatkan jabatan } \\
\text { akademik tertinggi } \\
\text { sampai Profesor. }\end{array}$ & & $\mathrm{x}$ & 4 & 0,17 \\
\hline 3 & $\begin{array}{l}\text { Kesempatan untuk } \\
\text { menjadi narasumber } \\
\text { diberbagai institusi }\end{array}$ & $\mathrm{x}$ & & 3 & 0,13 \\
\hline 4 & $\begin{array}{l}\text { Kesempatan } \\
\text { meneruskan } \\
\text { pendidikan terbuka } \\
\text { lebar }\end{array}$ & $\mathrm{x}$ & & 3 & 0,13 \\
\hline \multicolumn{6}{|c|}{ Ancaman (Threat) } \\
\hline 1 & $\begin{array}{l}\text { Sulitnya persyaratan } \\
\text { untuk memperoleh } \\
\text { jabatan fungsional } \\
\text { lektor kepala dan } \\
\text { guiru besar. }\end{array}$ & $\mathrm{x}$ & & 3 & 0,13 \\
\hline 2 & Adanya tawaran ke & $\mathrm{x}$ & & 3 & 0,13 \\
\hline
\end{tabular}




\begin{tabular}{|l|l|l|l|l|l|l|}
\hline & $\begin{array}{l}\text { dosen dari institusi } \\
\text { atau perguruan tinggi } \\
\text { lain yang } \\
\text { memberikan imbalan } \\
\text { yang lebih baik }\end{array}$ & & & & & \\
\hline 3 & $\begin{array}{l}\text { Banyak dosen } \\
\text { fisioterapi dari } \\
\text { perguruan tinggi lain } \\
\text { yang mampu } \\
\text { mempublikasikan } \\
\text { hasil penelitian di } \\
\text { Jurnal Internasional } \\
\text { bereputasi }\end{array}$ & & $\mathrm{x}$ & & 3 & 0,13 \\
\hline Total & & & & & & \\
\hline
\end{tabular}

Sumber : Lampiran 3, Data diolah

Tabel 5. IFAS (Internal Factor Analysis Summary)

\begin{tabular}{|l|l|l|l|l|}
\hline \multicolumn{2}{|l|}{ Faktor Strategi Internal } & Rating & Bobot & $\begin{array}{c}\text { Bobot x } \\
\text { Rating }\end{array}$ \\
\hline 1 & $\begin{array}{l}\text { Perguruan Tinggi Negeri yang } \\
\text { memberikan rasa aman }\end{array}$ & 4 & 0,12 & 0,48 \\
\hline 2 & $\begin{array}{l}\text { Prodi Fisioterapi masih jarang } \\
\text { diselenggarakan oleh perguruan } \\
\text { tinggi lain }\end{array}$ & 4 & 0,12 & 0,48 \\
\hline 3 & $\begin{array}{l}\text { Berada dalam posisi 5 Prodi } \\
\text { fisioterapi terbaik di Indonesia }\end{array}$ & 4 & 0,12 & 0,48 \\
\hline 4 & $\begin{array}{l}\text { Memiliki tim Dosen yang } \\
\text { bereputasi nasional dan } \\
\text { internasional }\end{array}$ & 3 & 0,09 & 0,27 \\
\hline
\end{tabular}




\begin{tabular}{|c|c|c|c|c|}
\hline 5 & $\begin{array}{l}\text { Sudah ada Pedoman/kebijakan } \\
\text { yang baku tentang sistem } \\
\text { pengelolaan SDM yang } \\
\text { dikeluarkan oleh Kemenkes } \\
\text { melalui Peraturan Menteri } \\
\text { Kesehatan Nomor } 33 \text { tahun } \\
2015 \text { tentang pedoman } \\
\text { penyusunan perencanaan } \\
\text { sumber daya kesehatan dan } \\
\text { sudah dilaksanakan dengan } \\
\text { transpran dan akuntabel }\end{array}$ & 4 & 0,12 & 0,48 \\
\hline & Total & & & 2,19 \\
\hline \multicolumn{5}{|c|}{ Kelemahan (WEAKNESS) } \\
\hline 1 & Guru Besar belum ada & 3 & 0,09 & 0,27 \\
\hline 2 & $\begin{array}{l}\text { Jabatan fungsional dosen masih } \\
\text { sedikit dan sebagian besar } \\
\text { masih Asisten Ahli }\end{array}$ & 3 & 0,09 & 0,27 \\
\hline 3 & $\begin{array}{l}\text { Jumlah penelitan dan publikasi } \\
\text { ilmiah secara kuantitas maupun } \\
\text { kualitas masih kecil }\end{array}$ & 2 & 0,06 & 0,12 \\
\hline 4 & $\begin{array}{l}\text { Jumlah dosen sesuai prodi } \\
\text { masih kurang }\end{array}$ & 3 & 0,09 & 0,27 \\
\hline 5 & $\begin{array}{l}\text { Dosen yang pendidikan S2 } \\
\text { kefisioterapian masih } \\
\text { kurang }\end{array}$ & 4 & 0,12 & 0,48 \\
\hline & Total & & 1 & 1,41 \\
\hline
\end{tabular}


Berdasarkan Tabel 5 dapat dilihat kekuatan (strength) yang dihasilkan oleh Prodi Fisioterapi dengan nilai rata-rata rating 4 yang berarti mempunyai nilai positif sangat besar (+) berarti, semua kekuatan yang ditimbulkan dapat digunakan untuk bersaing. Sedangkan untuk kelemahan (weakness), rating yang di dapat adalah 3 yang berarti memiliki pengaruh negative besar (-).

\section{Berikut Keterangan untuk rating:}

\section{Rating untuk kekuatan (strength)}

Nilai 1 : memiliki pengaruh positif sangat kecil

Nilai 2 : memiliki pengaruh positif kecil

Nilai 3 : memiliki pengaruh positif besar

Nilai 4 : memiliki pengaruh positif sangat besar

\section{Rating untuk kelemahan (weakness)}

Nilai 1 : memiliki pengaruh negatif sangat kecil

Nilai 2 : memiliki pengaruh negatif kecil

Nilai 3 : memiliki pengaruh negatif besar

Nilai 4 : memiliki pengaruh negatif sangat besar

Tabel 6. EFAS (External Factor Analysis Summary)

\begin{tabular}{|l|l|l|l|l|}
\hline \multicolumn{2}{|l|}{ Faktor Strategi Eksternal Rating } & Bobot & $\begin{array}{c}\text { Bobot x } \\
\text { Rating }\end{array}$ \\
\hline 1 & $\begin{array}{l}\text { Adanya kesempatan } \\
\text { memperoleh beasiswa untuk } \\
\text { pelatihan dan studi lanjut baik } \\
\text { dalam negeri maupun luar } \\
\text { negeri yang diberikan oleh } \\
\text { pemerintah }\end{array}$ & 0,17 & 0,68 \\
\hline 2 & $\begin{array}{l}\text { Terbukanya kesempatan dosen } \\
\text { Peluang }\end{array}$ & 4 & 0,17 & 0,68 \\
\hline
\end{tabular}




\begin{tabular}{|l|l|l|l|l|}
\hline & $\begin{array}{l}\text { vokasi untuk mendapatkan } \\
\text { jabatan akademik tertinggi } \\
\text { sampai Profesor. }\end{array}$ & & \\
\hline 3 & $\begin{array}{l}\text { Kesempatan untuk menjadi } \\
\text { narasumber diberbagai institusi }\end{array}$ & 3 & 0,13 & 0,39 \\
\hline 4 & $\begin{array}{l}\text { Kesempatan meneruskan } \\
\text { pendidikan terbuka lebar }\end{array}$ & 3 & 0,13 & 0,39 \\
\hline Ancaman (Threat) & $\begin{array}{l}\text { Sulitnya persyaratan untuk } \\
\text { memperoleh jabatan fungsional } \\
\text { lektor kepala dan guiru besar. }\end{array}$ & 3 & 0,13 & 0,39 \\
\hline 3 & $\begin{array}{l}\text { Banyak dosen fisioterapi dari } \\
\text { perguruan tinggi lain yang } \\
\text { mampu mempublikasikan hasil } \\
\text { penelitian di Jurnal } \\
\text { Internasional bereputasi }\end{array}$ & 3 & 0,13 & 0,39 \\
\hline 2 & $\begin{array}{l}\text { Adanya tawaran ke dosen dari } \\
\text { institusi atau perguruan tinggi } \\
\text { lain yang memberikan imbalan } \\
\text { yang lebih baik }\end{array}$ & 3 & 0,13 & 0,39 \\
\hline & $\begin{array}{l}\mid \\
\text { Total }\end{array}$ & $\mathbf{1}$ & \\
\hline & & & \\
\hline
\end{tabular}

Sumber Lampiran 3, Data diolah:

Berdasarkan Tabel 6 dapat dilihat peluang (opportunity) yang dihasilkan oleh Bahana Sekuritas dengan nilai rata-rata rating 4 yang berarti memiliki pengaruh positif sangat besar (+) dengan begitu peluang Bahana Sekuritas bisa dimanfaatkan menjadi kekuatan. Sedangkan untuk ancaman (threat), rating yang di dapat adalah 3 yang berarti memiliki pengaruh negatif besar $(-)$. 


\section{Keterangan :}

\section{Rating untuk peluang (opportunity)}

Nilai 1 : memiliki pengaruh positif sangat kecil

Nilai 2 : memiliki pengaruh positif kecil

Nilai 3 : memiliki pengaruh positif besar

Nilai 4 : memiliki pengaruh positif sangat besar

\section{Rating untuk ancaman (threat)}

Nilai 1 : memiliki pengaruh negatifsangat kecil

Nilai 2 : memiliki pengaruh negatif kecil

Nilai 3 : memiliki pengaruh negatif besar

Nilai 4 : memiliki pengaruh negatif sangat besar

\subsection{PENENTUAN POSISI PRODI FISIOTERAPI}

Menentukan prodi Fisioterapi dengan cara memadukan kekuatan(strength),kelemahan (weakness), peluang (opportunity), dan ancaman(threat)pada perusahaan sehingga dapat ditentukan titik koordinat dalam diagramSWOT.

1. Strategi Internal (S-W)

Dalam hal ini kekuatan (strength) mempunyai bobot (+) dan kelemahan (weakness) dengan bobot (-). Faktor Strategis Internal Perusahaan Bahana Sekuritas adalah:

1. Kekuatan = Jumlah Kekuatan faktor strategi internal $=5$

2. Kelemahan $=$ Jumlah Kelemahan faktor strategi $=4$

Dari hasil perhitungan di atas dapat diketahui bahwa faktor strategis internal perusahaan $2,19-1,41=(+) 0,78$

2. Strategi Eksternal (O-T)

Dalam hal ini peluang (opportunity) mempunyai bobot (+) dan ancaman (threat) mempunyai bobot (-). Faktor Strategis Eksternal Perusahaan $2,14-1,17=(+) 0,97$. 


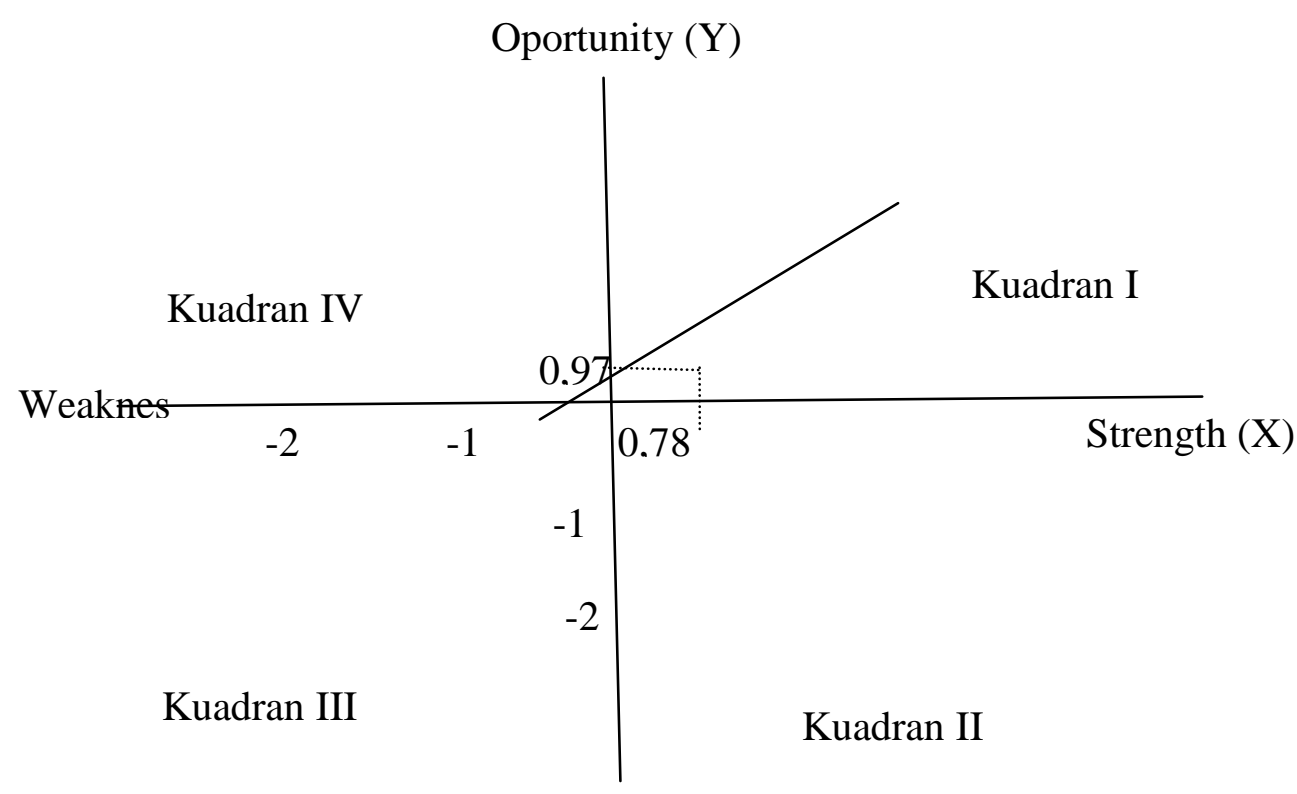

Threath

Gambar 4.7 : Posisi SWOT Perusahaan Bahana Sekuritas

Tujuan dari analisa dengan tools SWOT/TOWS adalah untuk menentukan strategi yang tepat bagi Prodi Fisioterapi dengan analisa bisnis jasa pendidikan dari sudut pandang internal ataupun external perusahaan. Berdasarkan penentuan posisi perusahaan, maka dapat diketahui bahwa perusahaan Prodi Fisioterapiberada pada kuadran 1, yaitu posisi perusahaan yang mendukung kebijakan yang agresif (Growth Oriented Strategy).

\section{SIMPULAN}

- Posisi perusahaan dalam penelitian ini adalah terdapat pada kuadran satu yaitu kuadran yang mendukung kebijakan pertumbuhan yang agresif, maksudnya perusahaan harus lebih giat dalam mengatasi perkembangan pasar yang kompetetif dalam rangka memperluas pangsa pasar.

- Kekuatan Five Porter sebagai berikut

1. Ancaman terhadap masuknya pesaing baru tergolong tinggi (skor $7,54)$

2. Ancaman terhadap produk baru juga tergolong Rendah $(2,8)$

3. Ancaman terhadap kekuatan tawar menawar Pembeli tergolong rendah (skor 1,8) 
4. Ancaman terhadap kekuatan tawar menawar pemasok tergolong rendah (skor 2,43)

5. Ancaman terhadap persaingan antar pesaing dalam industri sejenis tergolong tinggi (skor 7,67)

\section{DAFTAR PUSTAKA}

Bard Timothy. 2008. Opportunity Recognition. USA. Penerbit : Tim Bard Multimedia, Detroit Micighan.

Gregory Anne.2004. Public Relation in Practice. Second edition. USA. Penerbit

: Clays ltd.

Kotler, Philip. 2007. Manajemen Pemasaran. Edisi kelima. Jakarta: Erlangga.

Manktelow, James. Using the TOWS Matrix, (online). Available :http://www.mindtools.com/pages/article/newSTR_89.htm

Rangkuti, Fredy. 2006. Analisis SWOT: Teknik Membedah Kasus Bisnis Dan Analisa Kasus Cetakan kedua belas Jakarta: PT.Gramedia Pustaka Utama

Sutojo Siswanto dan F. Kleisteuber.2000.Strategic Marketing Manajemen, Strategi Manajemen. Jakarta. Penerbit : PT. Damar Mulia Pustaka Utama.

Citizen Lab and Canada centre for global Security Studies Munk School Of Global Affairs. 2014. Island of control, island of resistance, Monitoring The 2013 Indonesian IGF. Number 9. Published : 20 January 2014

Winninger, J. 2013, “Indonesia Netizen Survey 2013”, Marketeers edisi November 2013, vol.X, no.X, hal XX-XX.

Etterson, Condaro and Knowles, Harvard Business Review, Rethinking the 4P's, January-February 2013, (online) Available http://hbr.org/2013/01/rethinking-the-4-ps/ar/1

Tahir Ahmad Wani, Business Science International Reseach Journal, From PS To SAVE, 2013, Volume I Issue I, ISSN 2321-3191.

Wear, Sandra, "How to Compete on Value, Not Price" Inc. January 9, 2012, (online) Available at : http//www.inc.com/sandra-wear/how-to-completeon-value-not-

Gregory Ciotti, The New 4Ps of Marketing, July 23th 2013, (online) Available https://www.helpscout.net/blog/new-4ps-of-marketing/ 
Kevin-James Fenech, SAVE - updating the 4Ps, March 7 ${ }^{\text {th }}, 2013$ (online)

Available: http://www.timesofmalta.com/articles/view/20130307/businesscomment/Save-updating-the-4Ps.460523

IDX Yearly Statistic 2013 